\title{
Taxonomic Composition of Iris Subser. Chrysographes (Iridaceae) Inferred from Chloroplast DNA and Morphological Analyses
}

\author{
Eugeny V. Boltenkov ${ }^{1, *(\mathbb{D})}$, Elena V. Artyukova ${ }^{2}$ and Anna Trias-Blasi ${ }^{3}(\mathbb{D}$ \\ 1 Botanical Garden-Institute, Far Eastern Branch, Russian Academy of Sciences, 690024 Vladivostok, Russia \\ 2 Federal Scientific Center of the East Asia Terrestrial Biodiversity, Far Eastern Branch, Russian Academy of \\ Sciences, 690022 Vladivostok, Russia; artyukova@biosoil.ru \\ 3 Royal Botanic Gardens, Kew, Richmond TW9 3AE, UK; A.TriasBlasi@kew.org \\ * Correspondence: boltenkov@rambler.ru
}

check for

updates

Citation: Boltenkov, E.V.;

Artyukova, E.V.; Trias-Blasi, A.

Taxonomic Composition of Iris Subser.

Chrysographes (Iridaceae) Inferred

from Chloroplast DNA and

Morphological Analyses. Plants 2021,

10, 2232. https://doi.org/10.3390/

plants10112232

Academic Editors: Victoria Shneyer and Alexander Rodionov

Received: 30 September 2021

Accepted: 18 October 2021

Published: 20 October 2021

Publisher's Note: MDPI stays neutral with regard to jurisdictional claims in published maps and institutional affiliations.

Copyright: (c) 2021 by the authors. Licensee MDPI, Basel, Switzerland. This article is an open access article distributed under the terms and conditions of the Creative Commons Attribution (CC BY) license (https:// creativecommons.org/licenses/by/ $4.0 /)$.

\begin{abstract}
The species of Iris subser. Chrysographes are herbaceous perennials found mainly in southwestern and central China and also in the Eastern Himalayas. To date, six species have been recognized in this group. In the framework of its taxonomic revision, we have carried out molecular and morphological studies. For this, we have sequenced four chloroplast DNA regions (trnS-trnG, trnL-trnF, rps4-trnS $S^{\mathrm{GGA}}$, and $\left.p s b A-t r n H\right)$ for 25 samples across the major distribution ranges of the six species. Our phylogenetic analyses evidence that $I$. subser. Chrysographes is indeed a monophyletic group, which is sister to I. subser. Sibiricae. Within I. subser. Chrysographes, we have recovered four divergent lineages further supported by diagnosable morphological traits and geographical distributions. In this context, our data confirm the recognition of I. clarkei, I. delavayi, and I. wilsonii in their traditional concepts. Furthermore, both molecular and morphological data support the close affinities and similar distribution ranges of I. bulleyana, I. chrysographes, and I. forrestii, which suggests including I. chrysographes and I. forrestii as color forms in I. bulleyana. A revised taxonomic treatment for the group, including the notes on the species distributions and habitats, and also an identification key to the species are provided.
\end{abstract}

Keywords: chloroplast DNA; Chrysographes; Iris; molecular phylogeny; morphometry; taxonomy

\section{Introduction}

While revising the series Sibiricae (Diels) G.H.M.Lawr. of the section Limniris Tausch of the genus Iris L., we found that the taxonomy of this group remains unclear [1]. Iris ser. Sibiricae includes rhizomatous herbaceous perennials morphologically distinguished mainly by their hollow flowering stems (except for I. clarkei Baker ex Hook.f.). The infrageneric taxon Sibiricae was proposed by Diels [2] as a subsection including eight species. Simonet [3] subdivided this subsection into two groups on the basis of their chromosome numbers. Nevertheless, the distinctness of the two subseries, recognized on morphological ground and from their distributions [4,5], gained support from molecular studies [6,7].

Iris sibirica L., I. sanguinea Hornem., and I. typhifolia Kitag., with their $2 \mathrm{n}=28$ chromosomes [3,8,9], have been recognized in the autonymic subseries of $I$. ser. Sibiricae $[10,11]$ known to horticulturists under the common name "Siberian irises" [12]. In a recent study [1], we confirmed that I. subser. Sibiricae includes only the highly variable I. sibirica (Figure 1b,c). It is the most widespread Eurasian species of Iridaceae, occurring from central and eastern Europe to the Russian Far East. 


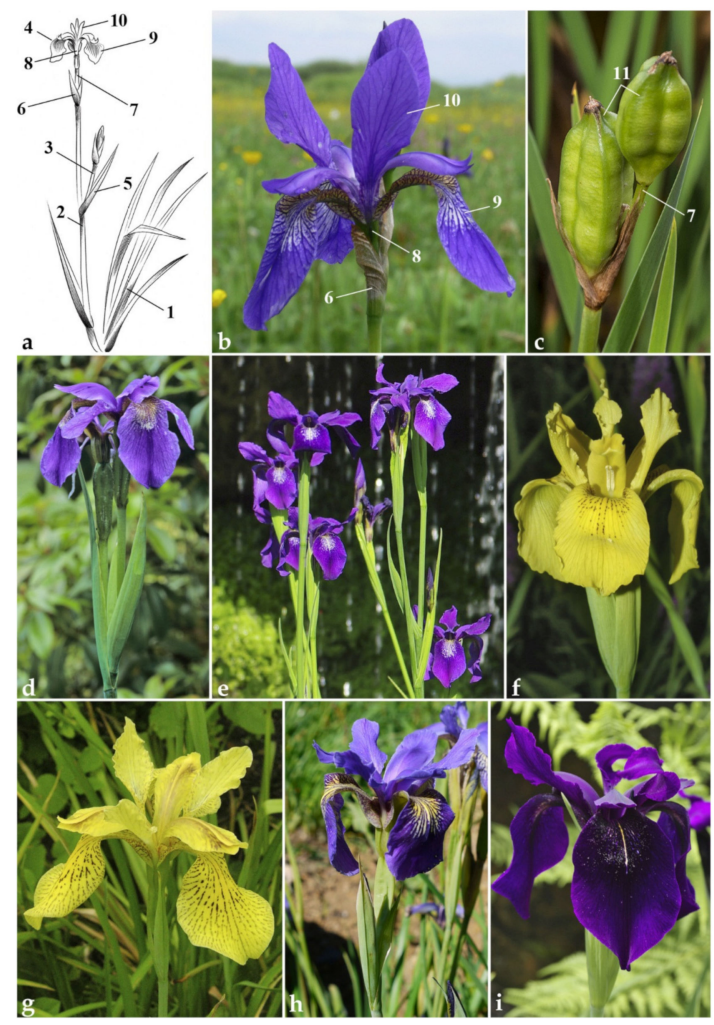

Figure 1. Morphological diversity in Iris ser. Sibiricae: (a) habitus; (b) I. sibirica, a flower (Carpathian Biosphere Reserve, Ukraine; by O. Kolesnyk); (c) I. sibirica, fruit (Russia, Karachay-Cherkessia; by T. Gaidash); (d) I. clarkei, flowers (cultivated plant; by RBGE staff); (e) I. delavayi, flowering stems (cultivated plant; by R. Wilford); (f) I. wilsonii, a flower (cultivated plant; by O. Fragman-Sapir); (g) I. forrestii, a flower (cultivated plant; by N. Shevyreva); (h) I. bulleyana, a flower (Litiping Plateau, Weixi Lisu Autonomous County, Yunnan Province, China; by I. Illarionova); (i) I. chrysographes, a flower (cultivated plant; by R. Wilford). Marks: 1, rosette leaf; 2 , flowering stem; 3 , branch; 4 , terminal flower; 5 , upper cauline leaf; 6 , outer bract; 7 , pedicel; 8 , tube; 9 , fall; 10 , standard; 11 , fruits.

Iris subser. Chrysographes (Simonet) L.W.Lenz species are distributed from northeastern India and southwestern China, Nepal, and Bhutan to northern Myanmar, and are found at mid- to high elevations $[11,13,14]$. The name Chrysographes was proposed by Simonet [3] as a subsection for the species with the chromosome number $2 n=40$. Alternatively, Chrysographes was referred to the genus Limniris (Tausch) Rchb. as a series [15], or a section [16], and is commonly known as "Sino-Siberians" among horticulturists [12]. Morphologically (see Figure 1), the I. subser. Chrysographes species is characterized by having longer bracts and perianth tube, and flowers without the venation characteristic of I. sibirica $[5,11,17]$.

As is recognized, I. subser. Chrysographes comprises eight species, I. bulleyana Dykes, I. chrysographes Dykes, I. clarkei, I. delavayi Micheli, I. dykesii Stapf, I. forrestii Dykes, I. phragmitetorum Hand.-Mazz., and I. wilsonii C.H.Wright; however, the taxonomy of some of them was considered controversial $[4,10,11,13,14,18]$. As a result of a preliminary taxonomic study based on an analysis of the original material [19], six species were attributed to I. subser. Chrysographes (Figure 1d-i). Among them, I. delavayi, I. wilsonii, I. bulleyana, and I. forrestii were described from cultivated plants. The examination of the original material has shown that I. delavayi, as well as I. bulleyana and I. forrestii (both from Lijiang), originated from the northwestern Yunnan Province, China, while I. wilsonii originated from the northwestern Hubei Province, China [19]. Iris clarkei and I. chrysographes were described from plants collected in the wild, from eastern India and the Sichuan Province (China), respectively.

Nevertheless, it was indicated that there remains a great deal of confusion about the I. subser. Chrysographes species from southwestern China, and a thorough revision is 
required to resolve the taxonomy of this group [10,20,21]. A doubt was expressed about whether I. bulleyana is an independent species. For years, I. bulleyana was suggested to be a natural hybrid between I. forrestii and I. chrysographes since, in the wild, these species grow in the same regions, and their natural hybridization is possible $[4,22]$. However, fieldwork in the Yunnan Province (China) showed that I. bulleyana is a true species and is sometimes found in associations with I. chrysographes or I. forrestii [11,14]. According to another point of view [21], I. chrysographes and I. bulleyana are considered extreme forms of a single species. In particular, Noltie [10] (p. 300) noted that no differentiation can be made between the two yellow-flowered I. forrestii and I. wilsonii when based solely on herbarium material, I. bulleyana is merely a purple-flowered form of the same species, and that I. chrysographes and I. delavayi are probably distinct species, though it is very difficult to distinguish between them in a herbarium.

In recent decades, much research has been conducted on plant barcoding using DNA sequences, including those of Iris [23-29]. Chloroplast DNA has been extensively used to investigate phylogenetic relationships in plants [30]. Sequences of many cpDNA noncoding regions, including introns and intergenic spacers, have been used to assess interspecific relationships and suggested as molecular markers for species identification [31]. The regions $t r n S-t r n G$, $t r n L-t r n F, r p s 4-t r n S^{\mathrm{GGA}}$, and $p s b A-t r n H$ of $\mathrm{cpDNA}$ have proven to be useful as phylogenetic markers in the genus Iris [1,32-34].

Accordingly, in the framework of taxonomic studies carried out on I. ser. Sibiricae $[1,19,35]$, the aims of the present study are as follows: (1) to resolve the phylogenetic relationships of the I. ser. Sibiricae species and some other series of I. sect. Limniris using four cpDNA regions; (2) to determine a possible number of putative chloroplast lineages within I. subser. Chrysographes; (3) to study the morphological characters of the I. ser. Sibiricae species; and (4) to compare the results of molecular and morphological studies to determining the taxonomic composition of I. subser. Chrysographes.

\section{Materials and Methods}

\subsection{Plant Samples, DNA Extraction, and Sequencing}

A total of 25 fully verified samples representing $I$. subser. Chrysographes were used for the molecular analyses. All samples were taken from living collections or herbarium specimens, of which three were of unknown geographical origin and the others were from 22 localities in southwestern China (Yunnan, Sichuan, and Xizang provinces), India, and Nepal (Figure 2). The complete list of samples, including their origin and voucher information, is provided in Table 1.

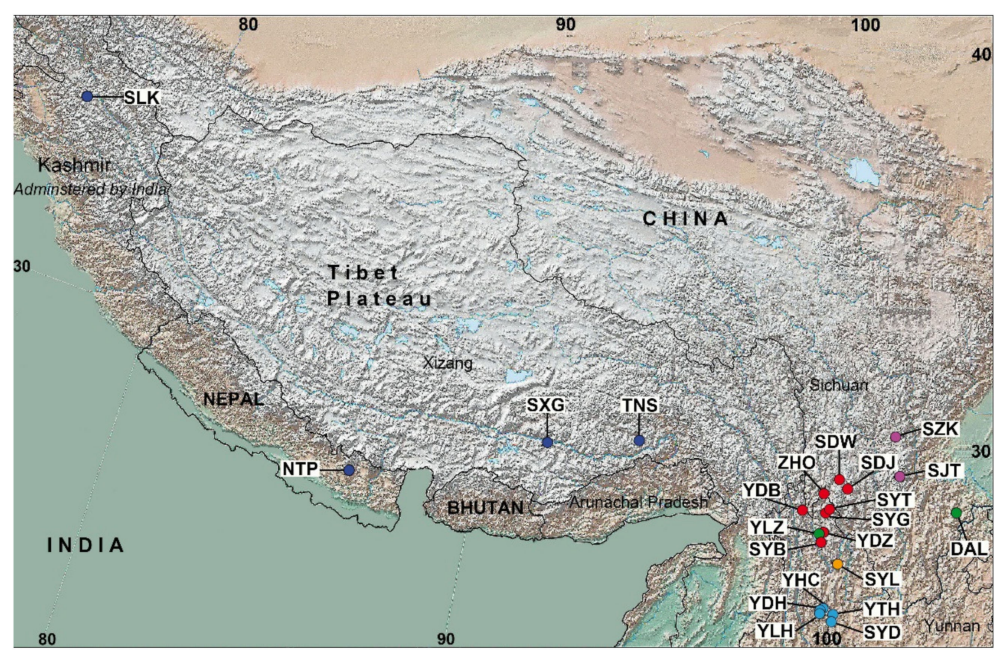

Figure 2. Map of Iris subser. Chrysographes localities. Codes correspond to entries in Table 1; cultivated plants (K6007, RUB, and K389) are not mapped. Circles represent localities: dark blue, I. clarkei; red, I. bulleyana; light purple, I. chrysographes; orange, I. forrestii; green, I. wilsonii; blue, I. delavayi. 
Table 1. Sampled taxa with voucher information and GenBank accession numbers.

\begin{tabular}{|c|c|c|}
\hline $\begin{array}{c}\text { Code } \\
\text { (Haplotype) }\end{array}$ & Locality (Voucher *) & 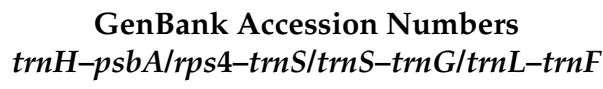 \\
\hline \multicolumn{3}{|c|}{ I. ser. Sibiricae subser. Chrysographes } \\
\hline $\mathrm{ZHO}(\mathrm{C} 1)$ & China, Yunnan, Zhongdian, M.G. Pimenov et al. 432 (MW) & LT627895/LT628011/LT628021/LT628001 \\
\hline SYB (C1) & China, Yunnan, Diqing, Beima Shan, AGS Expedition 866 (E) & LT978551/LT981293/LT984443/LT984476 \\
\hline SYG (C1) & \multirow{2}{*}{$\begin{array}{c}\text { China, Yunnan, Zhongdian, Geza, AGS Expedition } 509 \text { (E) } \\
\text { China, Yunnan, Zhongdian, Geza, Xiaoxue Shan, AGS } \\
\text { Expedition } 1890 \text { (E, cult.) }\end{array}$} & LT978550/LT981292/LT984442/LT984475 \\
\hline SYT (C1) & & LT978549/LT981291/LT984441/LT984474 \\
\hline YDB (C1) & \multirow{4}{*}{$\begin{array}{c}\text { China, Yunnan, Bai Ma Shan, B. Alden et al. } 1028 \text { (E, cult.) } \\
\text { China, Yunnan, Zhongdian, E.J. Cowley } 279 \text { (Kew No. } \\
\text { 1990-3337) } \\
\text { China, Sichuan, Daocheng, Sichuan Expedition } 273 \text { (E) } \\
\text { China, Sichuan, Daocheng, D.E. Boufford et al. } 28151 \\
\text { (E, cult.) }\end{array}$} & LR597324/LR597340/LR597356/LR597372 \\
\hline YDZ (C1) & & LR597325/LR597341/LR597357/LR597373 \\
\hline SDJ (C5) & & LR597326/LR597342/LR597358/LR597374 \\
\hline SDW (C6) & & LR597327/LR597343/LR597359/LR597375 \\
\hline \multicolumn{3}{|c|}{ I. forrestii } \\
\hline SYL (C4) & $\begin{array}{c}\text { China, Yunnan, Lijiang, Yulong Xueshan, P. Cox et al. } 2633 \\
\text { (E, cult.) }\end{array}$ & LT978553/LT981295/LT984445/LT984478 \\
\hline K389 (C3) & Origin unknown (Kew No. 2015-389) & LR597332/LR597348/LR597364/LR597380 \\
\hline \multicolumn{3}{|c|}{ I. chrysographes } \\
\hline SJT (C2) & China, Sichuan, Jiulong, Sichuan Expedition 331 (E) & LR597328/LR597344/LR597360/LR597376 \\
\hline SZK $(C 2)$ & China, Sichuan, Erskine et al. 364 (Kew No. 1988-4993) & LR597329/LR597345/LR597361/LR597377 \\
\hline K6007 (C2) & Origin unknown (Kew No. 1969-6007) & LR597331/LR597347/LR597363/LR597379 \\
\hline RUB (C2) & Cultivar "Rubella" (Kew No. 1949-59002) & LR597330/LR597346/LR597362/LR597378 \\
\hline \multicolumn{3}{|c|}{ I. delavayi } \\
\hline SYD (C7) & $\begin{array}{c}\text { China, Yunnan, Dali Xian, Yinglofen, Sino-Amer. Bot. } \\
\text { Expedition } 959 \text { (MHA) }\end{array}$ & LT978552/LT981294/LT984444/LT984477 \\
\hline YTH (C7) & $\begin{array}{l}\text { China, Yunnan, Tsang Shan, Little Huadianba, s.coll. } 1561 \\
\text { (E, cult.) }\end{array}$ & LR597333/LR597349/LR597365/LR597381 \\
\hline YHC (C7) & $\begin{array}{c}\text { China, Yunnan, Huadianba, Cang Shan Range, Brickell E } \\
\text { Leslie } 12617 \text { (Kew No. 1988-863) }\end{array}$ & LR597334/LR597350/LR597366/LR597382 \\
\hline YDH (C7) & $\begin{array}{l}\text { China, Yunnan, Tsang Shan, Huadianba, E.J. Cowley } 1399 \\
\text { (Kew No. 1990-3528) }\end{array}$ & LR597335/LR597351/LR597367/LR597383 \\
\hline YLH (C7) & $\begin{array}{l}\text { China, Yunnan, Tsang Shan, Little Huadianba, E.J. Cowley } \\
1561 \text { (Kew No. 1990-3549) }\end{array}$ & LR597336/LR597352/LR597368/LR597384 \\
\hline YLZ (C11) & $\begin{array}{c}\text { I. wilsonii } \\
\text { China, Yunnan, Little Zhongdian, E.J. Cowley } 566 \text { (Kew No. } \\
1990-3457)\end{array}$ & LR597339/LR597355/LR597371/LR597387 \\
\hline DAL2 (C12) & China, Sichuan, Daliang, s.coll. $1229(\mathrm{E})$ & LT978548/LT981290/LT984440/LT984473 \\
\hline \multicolumn{3}{|c|}{ I. clarkei } \\
\hline SXG (C8) & China, Tibet, Gongbogyamda, F. Ludlow et al. 14065 (E, cult.) & LT978546/LT981288/LT984438/LT984471 \\
\hline TNS (C9) & China, Xizang, Erskine et al. 52 (Kew No. 1996-245) & LR597337/LR597353/LR597369/LR597385 \\
\hline SLK (C9) & Ladakh, Kargil, C.A. Chadwell 82 (E, cult.) & LT978547/LT981289/LT984439/LT984472 \\
\hline NTP (C10) & Nepal, Trogsindho Pass, E.F. Needham 674 (E, cult.) & LR597338/LR597354/LR597370/LR597386 \\
\hline \multicolumn{3}{|c|}{ I. ser. Sibiricae subser. Sibiricae } \\
\hline (H1) & Mongolia, Dornod, Bayan-Uul, Gubanov 550 (MW) & LT978556/LT981298/LT984448/LT984480 \\
\hline$(\mathrm{H} 2)$ & $\begin{array}{c}\text { Russia, Primorsky Krai, Khankaysky District, Il'inka, } \\
\text { Pshennikova s.n. (VBGI) }\end{array}$ & LT978530/LT981272/LT984422/LT984455 \\
\hline (H3) & $\begin{array}{c}\text { Russia, Primorsky Krai, Pokrovka, Denisova E Talovskaya s.n. } \\
\text { (VBGI) }\end{array}$ & LT978532/LT981274/LT984424/LT984457 \\
\hline (H4) & Armenia, Lori, Tamanyan $\mathcal{E}$ al. 07-1189 (ERE) & LT978527/LT981269/LT984419/LT984452 \\
\hline (H5) & Russia, Sebezhsky District, Konechnaya s.n. (LE) & LT978538/LT981280/LT984430/LT984463 \\
\hline (H6) & Russia, Leningrad Oblast, near Vyborg, Boltenkov s.n. (LE) & LT978545/LT981287/LT984437/LT984470 \\
\hline (H7) & Russia, Setun River, Nasimovitch \& Shchukin s.n. (MHA) & LT978541/LT981283/LT984433/LT984466 \\
\hline (H8) & Georgia, Borjomi, Merello s.n. (LE) & LT978543/LT981285/LT984435/LT984468 \\
\hline
\end{tabular}


Table 1. Cont.

\begin{tabular}{|c|c|c|}
\hline $\begin{array}{c}\text { Code } \\
\text { (Haplotype) }\end{array}$ & Locality (Voucher *) & $\begin{array}{c}\text { GenBank Accession Numbers } \\
\text { trnH-psbA/rps4-trnS/trnS-trnG/trnL-trnF }\end{array}$ \\
\hline \multicolumn{3}{|c|}{ Outgroup specimens } \\
\hline $\begin{array}{l}\text { I. ensata } \\
\text { I. laevigata } \\
\text { I. pseudacorus }\end{array}$ & $\begin{array}{c}\text { I. ser. Laevigatae } \\
\text { Russia, Primorsky Krai, Zarubino, Boltenkov s.n. (VBGI) } \\
\text { Russia, Primorsky Krai, Roshchino, Pshennikova s.n. ( VBGI) } \\
\text { Russia, Vladivostok, Boltenkov s.n. (VBGI) }\end{array}$ & $\begin{array}{l}\text { LT628002/LT628022/LT628012/LT627896 } \\
\text { LT628003/LT628024/LT628013/LT627897 } \\
\text { LT628004/LT628025/LT628014/LT627898 }\end{array}$ \\
\hline $\begin{array}{l}\text { I. lactea } \\
\text { I. oxypetala } \\
\text { I.tibetica }\end{array}$ & $\begin{array}{c}\text { I. ser. Lacteae } \\
\text { Russia, Zabaykalsky Krai, Kharanor, Chernova s.n. (IRK) } \\
\text { China, Shaanxi, Suyde, Kabanov s.n. (LE) } \\
\text { China, Qinghai, Xining to Ta Er, Long et al. } 3 \text { (E) }\end{array}$ & $\begin{array}{l}\text { LT627854/LN871708/LN871662/LN871625 } \\
\text { LT627844/LT627950/LT627975/LT627911 } \\
\text { LT627893/LT627939/LT627998/LT627933 }\end{array}$ \\
\hline $\begin{array}{l}\text { I. uniflora } \\
\text { I. uniflora }\end{array}$ & $\begin{array}{c}\text { I. ser. Ruthenicae } \\
\text { Russia, Primorsky Krai, Anisimovka, Orlovskaya s.n. (VBGI) } \\
\text { Russia, Zabaykalsky Krai, Kyrinsky District, } \\
\text { Vologdina s.n. (VBGI) }\end{array}$ & $\begin{array}{l}\text { LT627832/LN871684/LN871640/LN871604 } \\
\text { LT628008/LT628029/LT628018/LT627902 }\end{array}$ \\
\hline I.dichotoma & $\begin{array}{l}\text { I. subgen. Pardanthopsis } \\
\text { Russia, Amur Oblast, Baranova s.n. (LE) }\end{array}$ & LT978555/LT981297/LT984447/LT984483 \\
\hline
\end{tabular}

${ }^{*}$ Herbarium codes according to Thiers [36]. Accession numbers in italics are reported in References [1,34]. Cult., cultivated.

The methods for DNA extraction, amplification, and direct sequencing of four noncoding cpDNA regions ( $t r n S-t r n G, t r n L-t r n F, r p s 4-t r n S G G A$, and $p s b A-t r n H)$ have been described elsewhere [32,37]. Forward and reverse sequences for each region were determined on a genetic analyzer ABI 3130 (Applied Biosystems, Bedford, MA, USA) at the Joint Center of Biotechnology and Gene Engineering, the Federal Scientific Center of the East Asia Terrestrial Biodiversity (Vladivostok, Russia), and assembled using the Staden Package, version 1.4 [38]. The sequences previously obtained for I. sibirica [1] were also included in the analyses. In phylogenetic analyses, we also used the sequences previously published for representatives of three series of I. sect. Limniris [33,34]. These are (1) I. laevigata Fisch., I. ensata Thunb., and I. pseudacorus L. from I. ser. Laevigatae (Diels) G.H.M.Lawr.; (2) I. lactea Pall., I. oxypetala Bunge, and I. tibetica (Dykes) Bolt. from I. ser. Lacteae Doronkin; and (3) I. uniflora Pall. ex Link from I. ser. Ruthenicae (Diels) G.H.M.Lawr. In addition, I. dichotoma Pall. from I. subgen. Pardanthopsis (Hance) Baker was used as outgroup. The sequences obtained were deposited in the European Nucleotide Archive database. The accession numbers for all the sequences used are listed in Table 1.

\subsection{Sequence Alignment and Phylogenetic Analyses}

The sequences of each cpDNA region were aligned manually in SeaView, version 4 [39], and concatenated for each specimen. We included indels and length variation in mononucleotide repeats in the dataset because repeatability tests allowed excluding PCR errors. The haplotypes were identified based on combined DNA sequences using DnaSP, version 5 [40]. A network of haplotypes was constructed using Network, version 4.6 [41], with treating each deletion/insertion, regardless of size, as a single mutational event and using the MJ algorithm with default settings.

Phylogenetic analyses were conducted using the ML and MP methods as implemented in PAUP, version 4.0 b10 [42]. Bayesian analysis was performed using MrBayes, version 3.2.2 [43] via the CIPRES portal [44]. The dataset was composed of sequences from the $I$. subser. Chrysographes specimens, haplotypes H1-H8 of I. subser. Sibiricae [1], and sequences of species from three other series of I. sect. Limniris (i.e., Laevigatae, Lacteae, and Ruthenicae) and I. dichotoma as outgroup. For the MP analysis, gaps were coded according to the simple indel coding procedure [45] as implemented in FastGap, version 1.2 [46]. Optimal trees were found using a heuristic search with TBR branch swapping and the MulTrees option in effect. For ML and BI analyses, the GTR + I + G model was selected according to the Akaike information criterion using Modeltest, version 3.6 [47]. ML heuristic searches were done 
using the resulting model settings, 100 replicates of random sequence addition, TBR branch swapping, and MULTrees option on. In BI, using the default prior settings, two parallel MCMC runs were carried out for 10 million generations, sampling every 1000 generations for a total of 10,000 samples. Convergence of the two chains was assessed, and PP were calculated from the trees sampled during the stationary phase. The robustness of nodes in ML and MP trees was tested using bootstrap with 1000 replicates (BP).

The degrees of divergence between the groups identified in the MJ and phylogenetic analyses were calculated based on nucleotide substitutions using DnaSP. The distribution of genetic variation within and among these groups and $F_{\mathrm{ST}}$ among them was determined by AMOVA as implemented in Arlequin, version 3.5 [48]. The significance of the variance components and genetic distances were tested using 1000 random permutations.

\subsection{Morphological Data}

The main taxonomic works dealing with $I$. subser. Chrysographes were consulted $[4,10,11,13,14,18]$. In order to clarify morphological characters of the species and compile the morphological key, the herbarium specimens deposited at BM, E, K, and LE (herbarium codes according to Thiers [36]), including the type material of the names studied, were examined personally by the authors [19]. In addition, the specimens have been searched through high-resolution images available in virtual herbaria: BNU, CDBI, HITBC, HNWP, IBK, IBSC, IMC, IMDY, JIU, KUN, LBG, NAS, PEM, Shangri-la Alpine Botanic Garden (as SABG), SZ, WCSBG and XBGH (https: / / www.cvh.ac.cn/; accessed on 15 September 2021), BM (https://data.nhm.ac.uk/dataset/collection-specimens; accessed on 15 September 2021), E (https://data.rbge.org.uk/search/herbarium/; accessed on 15 September 2021), K (http:/ / apps.kew.org/herbcat/navigator.do; accessed on 15 September 2021), AMD, L and U (http://bioportal.naturalis.nl/; accessed on 15 September 2021), P (https:/ / science.mnhn.fr/institution/mnhn/collection/p/item/ search; accessed on 15 September 2021), and PE (http://pe.ibcas.ac.cn/en/; accessed on 15 September 2021). For the morphological study of the I. ser. Sibiricae species, sixteen descriptive characters were selected based on studies of the dedicated literature and herbarium specimens (Table 2 and Table S1, Figure 1a-c). Since the collected data were used to identify morphological distinctions in the entire series studied, we, hence, incorporated the detailed data on I. sibirica from recent work [1].

Table 2. Morphological characters analysed in the Iris ser. Sibiricae species.

\begin{tabular}{|c|c|c|c|}
\hline No. & Character & Code * & Description/Remarks \\
\hline 1 & Rosette leaf length & LL & $\begin{array}{l}\text { Measured from the base to the apex of the longest } \\
\text { central leaf in a rosette }\end{array}$ \\
\hline 2 & Rosette leaf width & LW & $\begin{array}{c}\text { Measured at the broadest part of the } \\
\text { widest rosette leaf }\end{array}$ \\
\hline 3 & Flowering stem height & $\mathrm{SH}$ & $\begin{array}{l}\text { Measured from the base of flowering stem to the } \\
\text { base of outer bract }\end{array}$ \\
\hline 4 & Flowering stem structure & - & $\begin{array}{c}\text { Internal structure of flowering stem according to the } \\
\text { literature data }\end{array}$ \\
\hline 5 & Flowering stem branching & IS & $\begin{array}{l}\text { Classified as unbranched (designated as 1; see Table } \\
\text { S1), 1-branched (2), and 2-branched (3) inflorescence }\end{array}$ \\
\hline 6 & Number of flowers & NF & Flowers per stem \\
\hline 7 & Number of cauline leaves & $\mathrm{NC}$ & Leaves on the flowering stem nodes \\
\hline 8 & Cauline leaf length & $\mathrm{CL}$ & $\begin{array}{c}\text { Measured from the base to the apex of the upper } \\
\text { cauline leaf }\end{array}$ \\
\hline
\end{tabular}


Table 2. Cont.

\begin{tabular}{|c|c|c|c|}
\hline No. & Character & Code * & Description/Remarks \\
\hline 9 & Bract length & BL & Measured from the base to the apex of outer bract \\
\hline 10 & Pedicel length & PL & $\begin{array}{l}\text { Measured from the base of terminal head to the } \\
\text { ovary base of the first blooming flower }\end{array}$ \\
\hline 11 & Tube length & $\mathrm{TL}$ & Measured from the ovary apex to the base of falls \\
\hline 12 & Flower color & - & $\begin{array}{l}\text { The basic flower color according to the literature } \\
\text { data and herbarium labels }\end{array}$ \\
\hline 13 & Falls ornamentation & - & $\begin{array}{l}\text { Markings (lines and spots) on blades of outer } \\
\text { perianth segments (falls), according to the literature } \\
\text { data and herbarium labels }\end{array}$ \\
\hline 14 & Standards arrangement & - & $\begin{array}{c}\text { The spatial arrangement of the inner perianth } \\
\text { segments (standards), according to the } \\
\text { literature data }\end{array}$ \\
\hline 15 & Fruit length & FL & $\begin{array}{l}\text { Obtained for the first fruit of terminal head from } \\
\text { specimens at fruiting (designated as "[fr.]"; see } \\
\text { Annex 1) }\end{array}$ \\
\hline 16 & Fruit shape & - & Obtained from specimens at fruiting \\
\hline
\end{tabular}

* The codes are provided for the characters examined in the herbarium specimens.

In a total, 540 specimens (see Annex 1) of well-developed plants in flowering and fruiting stages, collected from Bhutan, China, India, and Nepal, we examined based on the qualitative and quantitative morphological characters useful to distinguish species. The herbarium specimens were identified on the basis of our own experience in dealing with this group. The quantitative characters were measured using AxioVision, version 4.8 (Carl Zeiss, Germany).

\subsection{Morphometric Analysis}

Our morphometric analysis of I. bulleyana, I. chrysographes, I. delavayi, and I. forrestii was based on eight quantitative (BL, CL, LL, LW, NC, NF, PL, and SH) and one qualitative (IS) characters (Table 2). As the dataset of I. delavayi was limited to 13 individuals, for statistical analysis, we randomly selected 13 samples for each species from the initial dataset by using the built-in resample function of the $\mathrm{R}$ free software for statistical analysis [49], version 4.1 [50]. The dataset was analyzed by using one-way ANOVA. Differences were considered statistically significant at a $p$-value $<0.05$. After a multiple statistical testing was performed, the calculated $p$-values were adjusted using the procedure proposed by Benjamini and Hochberg [51]. To test one-way ANOVA assumptions, the Shapiro-Wilk's test for normality of distribution [50] and Levene's test for equality of variances [52] were used. If an ANOVA showed a statistically significant difference among species, then subsequent pairwise comparisons were made using the Tukey's post-hoc test [53]. Inequality of variance was taken into account by using the heteroscedastic consistent covariance estimation provided in the R add-on package "sandwich", version 2.3.0 [54,55]. Analysis of the countable characters (NF and NC) was done by the Poisson regression using the respective $\mathrm{R}$ built-in function [50].

We conducted the PCA analysis [56] to visualize the distribution of species over the space of quantitative multivariate data and to assess their delimitation. The characters were considered taxonomically useful when overlap was equal to or lower than a threshold of $25 \%$ [57]. The PCA analysis was performed using the built-in function prcomp, and the results of the analysis were extracted and visualized using the respective functions of the factoextra R package [58]. CV (\%) was calculated for the six quantitative characters (Table S2). Values of CV were classified in four categories: minor variation (0-10), little variation (11-20), average variation (21-40), and high variation (41-60). All statistical analyses were performed using the R Statistical Software, version 4.1 [50]. 


\subsection{Taxonomy and Distribution}

Here, the conservative taxonomy of Iris is used $[2,6,7,10,13,14,22,24]$. The types of the I. subser. Chrysographes names were selected in a recent nomenclatural study [19]. For the taxonomy, the Shenzhen Code [59] was consulted. In the case of disagreement on the infraspecific rank at which a name should be accepted, we followed Brummitt [60]. In the Taxonomic treatment section (see below), we extracted the information on distribution of the accepted taxa from the herbarium specimens. We also consulted the information provided in References $[4,10,11,13,14,18,20,22,61]$, which are commonly recognized as taxonomically reliable sources.

\section{Results}

\subsection{Genetic Divergence of Chloroplast Non-Coding Sequences within Iris Subser. Chrysographes}

Among the 25 specimens of I. subser. Chrysographes, 12 haplotypes (C1-C12; see Table 1) were identified on the basis of polymorphic sites detected across 3704 aligned positions of four cpDNA regions. Four of these haplotypes (C1, C2, C7, and C9) were found in several localities, sometimes geographically very distant from each other (e.g., C9 in SLK and TNS from India and Nepal, respectively), while the others were unique, i.e., found in a single locality.

The relationships between haplotypes found in representatives of $I$. ser. Sibiricae are shown in Figure 3. All haplotypes of I. ser. Sibiricae are connected into a single network without loops and derived from the same extinct ancestral haplotype related through many mutational steps with the haplotype of I. pseudacorus. Haplotypes of I. subser. Chrysographes (C1-C12) are separated by 29 mutational steps from haplotypes of I. subser. Sibiricae (H1-H8) closely related to each other. The more heterogeneous haplotypes of $I$. subser. Chrysographes form four groups (A-D) separated from each other by multiple (from 6 to 15) mutational steps (Figure 3). Haplogroup A contains six closely related haplotypes (C1-C6), most of which differ by only one mutational step from C2, forming a star-like structure indicative of a rapid range expansion in the past. Haplotypes of this group are found in samples of I. bulleyana (C1, C5, and C6), as well as in samples of I. chrysographes (C2) and I. forrestii (C3 and C4).

Haplogroup B includes one haplotype C7, which was found in samples from different localities near the Cang Mountains (Yunnan Province, China), and is separated from haplogroup A by 7 mutational steps. Haplogroups $C$ and D are separated from each other by 11 mutational steps and from other two haplogroups (A and B) by 12-14 mutational steps including 9-bp insertion in the $t r n L-t r n F$ region. Haplotypes of $C$ group were found in the specimens from the Xizang Province, China (C8 in SXG and C9 in TNS), and the Eastern Himalayas (C9 and C10 in SLK and NTP, respectively). Haplotypes C11 and C12 of haplogroup D were found in the I. wilsonii specimens: YLZ from Shangri-La (formerly known as Zhongdian; Yunnan, China) and DAL from the Daliang Mountains (Sichuan, China). The pairwise $F_{\mathrm{ST}}$ values between four haplogroups varied from 0.609 to $0.929(p<0.05)$, and $K_{\mathrm{S}}$ varied from 0.00374 to 0.00447 .

In all the phylogenetic analyses, Iris accessions were distributed with a robust support (PP 1.0, BP 100 and 100\%) in accordance with their affiliation to the corresponding series of $I$. sect. Limniris (Figure 4). Iris ser. Sibiricae was resolved as a monophyletic group (PP 1.00, BP 100 and $100 \%$ ) consisting of two strongly supported sister clades corresponding to $I$. subser. Sibiricae (PP 1.0, BP 100 and 100\%) and I. subser. Chrysographes (PP 1.0, BP 100 and 100\%) that are recognized in this group. The pairwise $F_{\mathrm{ST}}$ between these subseries was 0.825 $(p=0.00001)$, and $K_{\mathrm{S}}$ between them was 0.00892. Within clade I. subser. Chrysographes, there was a polytomy of three monophyletic clusters, with the divergence between them varying from 0.00408 to 0.00440 (Table S3). In cluster I (PP 1.0, BP 99 and 98\%), two sister groups, A and B, were resolved with a support of PP 1.0, BP 97 and 95\% and PP 0.93, BP 86 and $85 \%$, respectively. These groups corresponded to haplogroups $A$ and $B$ revealed by the MJ-network analysis (Figure 3). The pairwise $F_{\mathrm{ST}}$ between these haplogroups was 0.86 $(p=0.00001)$, and $K_{\mathrm{S}}$ between them was 0.00153 . The nucleotide divergence between the 
sequences of species comprising haplogroup A (I. bulleyana, I. forrestii, and I. chrysographes, hereinafter referred to as the bulleyana group) varied from 0.00023 to 0.00063 (Table S3). The pairwise $F_{\mathrm{ST}}$ values between them varied from 0.385 to 0.419 and were not significant $(p>0.05)$. No nucleotide substitutions or indels differentiating these species were revealed. The sequence divergence between each of these species and I. delavayi (from haplogroup B, Cluster I) was higher and varied from 0.00133 to 0.00173 . Clusters II and III were consistent with haplogroups C and D, which was revealed by the MJ-network analysis (Figure 3).

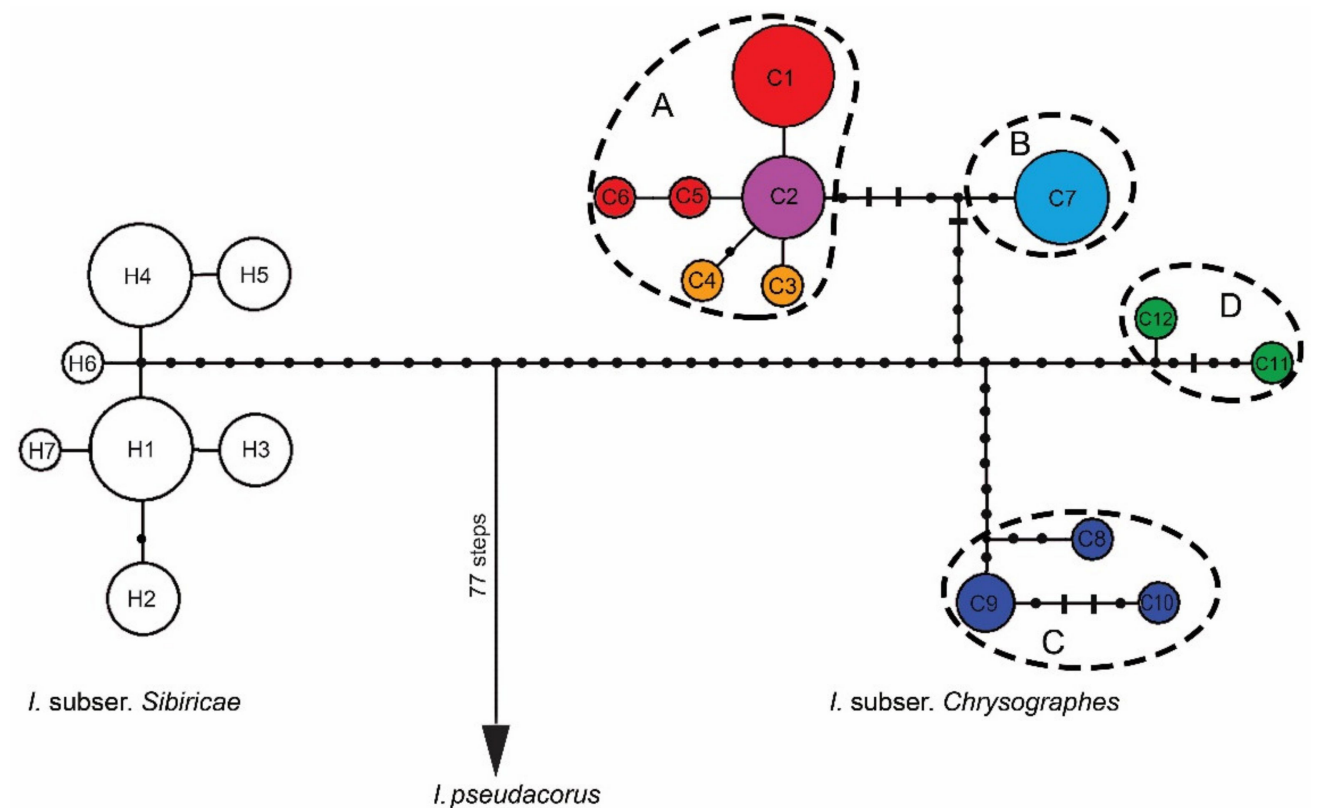

Figure 3. Median-joining networks inferred from combined sequences of the $\operatorname{trn} \mathrm{S}-\operatorname{trn} \mathrm{G}, \operatorname{trn} \mathrm{L}-\operatorname{trn} \mathrm{F}$, $r p s 4-t r n S^{G G A}$, and $p s b \mathrm{~A}-t r n \mathrm{H}$ regions showing the relationships among cpDNA haplotypes of the Iris ser. Sibiricae species and I. pseudacorus as outgroup. Each circle indicates a haplotype, with the size of the circle proportional to the number of populations where this haplotype is found. The colors of circles indicate the affiliation of haplotype: white, I. sibirica; red, I. bulleyana; light purple, I. chrysographes; orange, I. forrestii; blue, I. delavayi; green, I. wilsonii; dark blue, I. clarkei. Black dots indicate intermediate haplotypes not observed in the samples; short bars indicate indels; the haplotypes outlined by dashed lines represent groups A-D within I. subser. Chrysographes. For haplotype codes, see Table 1.

\subsection{Morphological Study}

To evaluate the taxonomic significance of the molecular results, we performed a morphological study of the I. ser. Sibiricae species. The main diagnostic characters that allow distinguishing between the I. ser.Sibiricae species are summarized in Table 3. Morphologically, the I. subser. Chrysographes species are distinguished from I. sibirica by their longer bracts (most commonly more than $6 \mathrm{~cm}$ in length), which are also green at blooming (dry in I. sibirica), by the $1-2.2 \mathrm{~cm}$ long perianth tube (not longer than $0.5 \mathrm{~cm}$ in $I$. sibirica), and by the slightly veined ornamentation of the falls (strongly veined in I. sibirica; see Figure 1). 


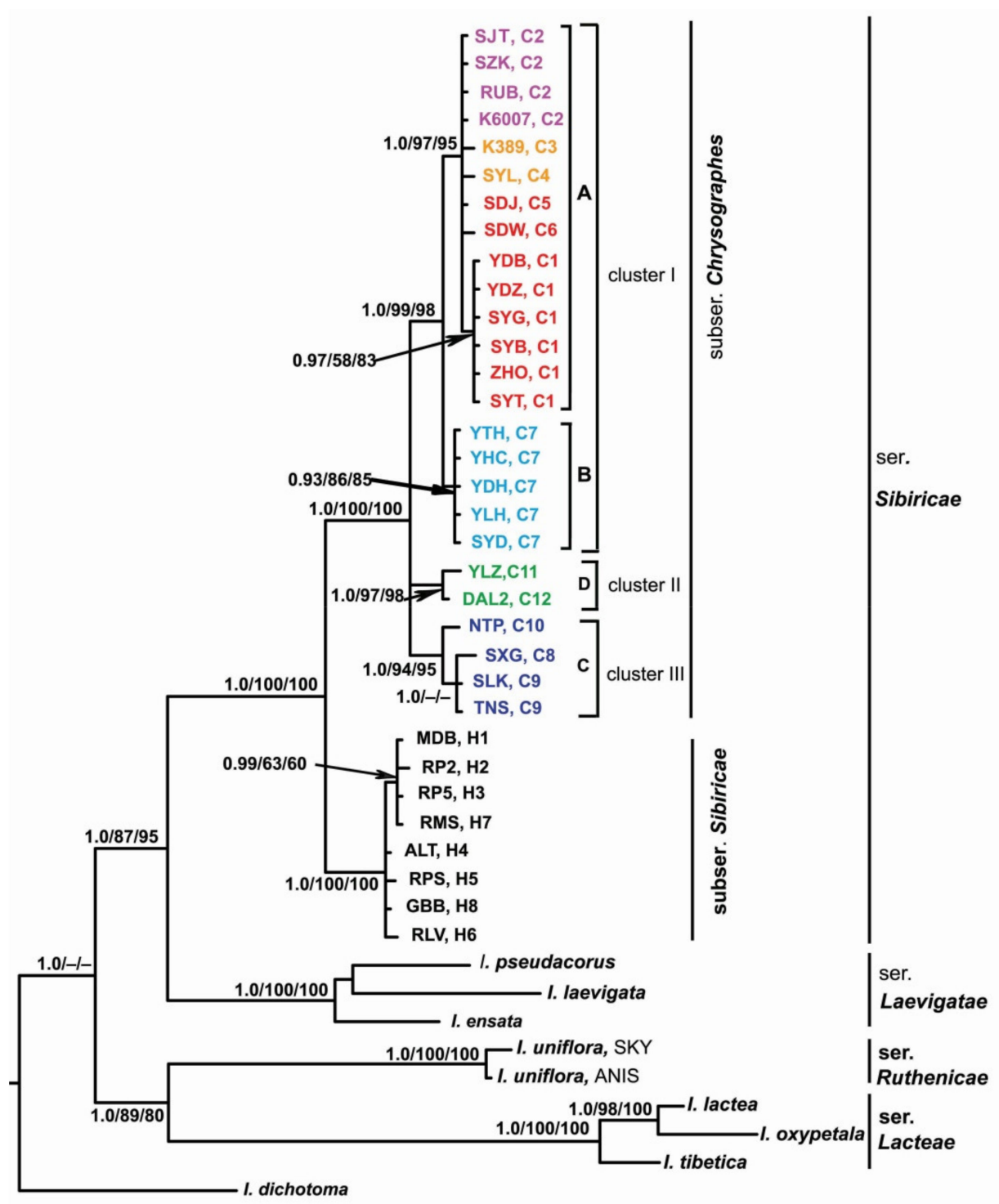

Figure 4. The Bayesian majority rule consensus tree of the Iris ser. Sibiricae samples inferred from combined trnS-trnG, trnL-trnF, rps4-trnS GGA, and $p s b A-t r n H$ chloroplast data. The numbers above the branches are Bayesian posterior probabilities $(\mathrm{PP}>0.9)$ and bootstrap values $(>50 \%)$ for MP and ML analyses. The haplotype and locality codes correspond to those in Table 1. A, B, C, and D indicate the haplogroups in Figure 3. Color indicates the affiliation of haplotype: light purple, I. chrysographes; orange, I. forrestii; red, I. bulleyana; blue, I. delavayi; green, I. wilsonii; dark blue, I. clarkei.

The results have shown as follows (Table 3): (1) I. clarkei is the only species in I. ser. Sibiricae with solid flowering stems (the rest of the species have hollow stems), which are 1-2-branched; (2) I. delavayi is the tallest species, having 1-branched flowering stems up to $114 \mathrm{~cm}$ long, which are usually higher than basal leaves; (3) I. forrestii and I. wilsonii, which are the only two yellow-flowered species, appear quite similar, with, however, I. wilsonii being generally more vigorous, having elongated cauline leaves up to $40 \mathrm{~cm}$ long (in $I$. forrestii, not longer than $25 \mathrm{~cm}$ ), flowering stems of about the same length as basal leaves, and pale yellow flowers born on elongated pedicels up to $11 \mathrm{~cm}$ long (in I. forrestii, flowers are clear yellow with brownish-purple lines on the haft, and pedicels not exceeding $8 \mathrm{~cm}$ in length); and (4) I. bulleyana, I. chrysographes, and I. forrestii are morphologically most closely related, while differing mainly in the color of flowers. 
Table 3. Morphological characteristics of the Iris ser. Sibiricae species.

\begin{tabular}{|c|c|c|c|c|c|c|c|}
\hline Character & I. sibirica * & I. clarkei & I. delavayi & I. wilsonii & I. forrestii & I. bulleyana & $\begin{array}{l}\text { I. chryso- } \\
\text { graphes }\end{array}$ \\
\hline $\begin{array}{l}\text { Rosette leaf } \\
\text { length }\end{array}$ & 24-99 & $41-76$ & $24-66$ & $22-72$ & $11-63$ & $12-56$ & $16-58$ \\
\hline $\begin{array}{l}\text { Rosette leaf } \\
\text { width }\end{array}$ & $0.2-1.1$ & $0.8-1.4$ & $0.6-1.5$ & $0.4-1.1$ & $0.2-0.9$ & $0.2-1.1$ & $0.2-1.1$ \\
\hline $\begin{array}{l}\text { Flowering } \\
\text { stem height }\end{array}$ & $22-99$ & $17-84$ & 21-114 & $17-70$ & $4-58$ & $5-73$ & $9-68$ \\
\hline $\begin{array}{c}\text { Flowering } \\
\text { stem } \\
\text { structure }\end{array}$ & Hollow & $\begin{array}{l}\text { Solid (narrow } \\
\text { central } \\
\text { hollow?) }\end{array}$ & Hollow & Hollow & Hollow & Hollow & Hollow \\
\hline $\begin{array}{l}\text { Flowering } \\
\text { stem } \\
\text { branching }\end{array}$ & $0-1$ & $0-2$ & 1 & $0(1 ?)$ & 0 & 0 & 0 \\
\hline $\begin{array}{l}\text { Number of } \\
\text { flowers }\end{array}$ & $1-6$ & $2-5$ & $2-3$ & $1-2(3 ?)$ & $1-2$ & $1-2$ & $1-2$ \\
\hline $\begin{array}{c}\text { Number of } \\
\text { cauline } \\
\text { leaves }\end{array}$ & (0)1-2(3) & $2-4$ & $1-5$ & $1-2$ & (0)1-2(3) & (0)1-2(3) & (0)1-2(3) \\
\hline $\begin{array}{c}\text { Cauline leaf } \\
\text { length }\end{array}$ & $4-25$ & $7-13$ & $7-19$ & $10-39$ & $6-25$ & $6-23$ & $7-25$ \\
\hline Bract length & $2-6(7)$ & $6-9$ & $6-10$ & $6-11$ & $3-8$ & $4-13$ & $5-13$ \\
\hline $\begin{array}{l}\text { Pedicel } \\
\text { length }\end{array}$ & $0.4-6$ & $3-10$ & $2-10$ & $3-11$ & $1.5-8$ & $1.2-8$ & $1.3-9$ \\
\hline Tube length & $\leq 0.5$ & $1.1-1.8$ & $1.1-1.8$ & $1.1-1.9$ & $1-1.8$ & $1-2.1$ & $1-2.2$ \\
\hline Flower color & Blue to violet & $\begin{array}{l}\text { Deep blue to } \\
\text { violet blue }\end{array}$ & $\begin{array}{l}\text { Light to dark } \\
\text { purple-blue }\end{array}$ & Pale yellow & $\begin{array}{l}\text { Lemon- } \\
\text { yellow }\end{array}$ & $\begin{array}{c}\text { Pale blue to } \\
\text { mauve and } \\
\text { violet }\end{array}$ & $\begin{array}{c}\text { Reddish } \\
\text { violet to deep } \\
\text { violet }\end{array}$ \\
\hline $\begin{array}{l}\text { Falls orna- } \\
\text { mentation }\end{array}$ & White & $\begin{array}{l}\text { Pale yellow } \\
\text { at base; white }\end{array}$ & White at base & $\begin{array}{c}\text { Purplish at } \\
\text { base }\end{array}$ & $\begin{array}{l}\text { Brownish- } \\
\text { purple }\end{array}$ & $\begin{array}{l}\text { White or } \\
\text { yellow }\end{array}$ & Yellow \\
\hline $\begin{array}{c}\text { Standards } \\
\text { arrangement }\end{array}$ & Erect & $\begin{array}{l}\text { Strongly } \\
\text { inclined }\end{array}$ & $\begin{array}{l}\text { Obliquely } \\
\text { spreading }\end{array}$ & Nearly erect & $\begin{array}{c}\text { Inclined at } \\
45^{\circ}\end{array}$ & $\begin{array}{c}\text { Inclined at } \\
45^{\circ}\end{array}$ & $\begin{array}{c}\text { Inclined at } \\
45^{\circ}\end{array}$ \\
\hline Fruit length & $1.5-7.7$ & $3-6$ & $4.5-6$ & $2.5-5$ & $2-5$ & $2-7$ & $2.8-7$ \\
\hline Fruit shape & $\begin{array}{l}\text { Oblong } \\
\text { ellipsoidal }\end{array}$ & $\begin{array}{l}\text { Oblong } \\
\text { ellipsoidal }\end{array}$ & $\begin{array}{l}\text { Oblong } \\
\text { cylindrical }\end{array}$ & Ellipsoidal & Ellipsoidal & Ellipsoidal & Ellipsoidal \\
\hline
\end{tabular}

* According to Reference [1]. All measurements are expressed in centimeters. See supplementary raw data in Table S1 for more details. Descriptions of the characters and their codes are provided in Table 2; for illustrations, see Figure 1.

Eigenvalues of the measurable morphological characters (principal components), which were essential to the observed variations between the taxa, are given in Table S2. Variables CL, LL, LW, NC, NF, and SH had the largest share in the separation of the species of the bulleyana group and I. delavayi, the closely allied species according to our molecular data. The cumulative percentage of the explained variance was $68.74 \%$. A further analysis showed a statistically significant difference in BL and PL between I. delavayi on the one hand, and between I. bulleyana and I. forrestii on the other ( $p=0.0012$ and $p<0.0001$, respectively). Between the species of the bulleyana group, no statistically significant difference was found in BL, CL, LL, NC, NF, and PL. A significant difference in LW and SH was found in the pair I. forrestii and I. chrysographes; the other pairs of species in the bulleyana group did not show any difference.

The PCA of the quantitative characters of the estimated variance component for all the samples gave values of $46.2 \%$ and $11.5 \%$, respectively, for the first two principal components (Figure 5). Two characters, NF and PL, displayed the highest correlations with the first (NF, $r=0.85$ ) and the second axis (PL, $r=0.60$ ); the third one, CL, highly influenced the third axis (CL, $r=-0.83)$. In the PCA scatter-plot of all the individuals in the plane defined by the first two principal components (Figure 5), the studied specimens grouped together in accordance with their taxonomic affiliation, creating two separate groups. The first one included the species of the bulleyana group, and the second one 
included I. delavayi (Figure 5). An examination of the biplot (Figure 5) from first two principal components revealed a partial overlapping of I. bulleyana, I. chrysographes, and I. forrestii and also their significant morphological similarity. The separation of I. delavayi from the other three taxa was defined by the first two principal components. Thus, having likely different average values of some morphometric characters caused by environmental conditions and interspecific trait variability, I. bulleyana, I. chrysographes, and I. forrestii can still be considered as indistinguishable in a generalized (PCA) factor space. Therefore, the result of PCA proved to be the same as that of the molecular study, and it was sufficient to supplement molecular evidence.

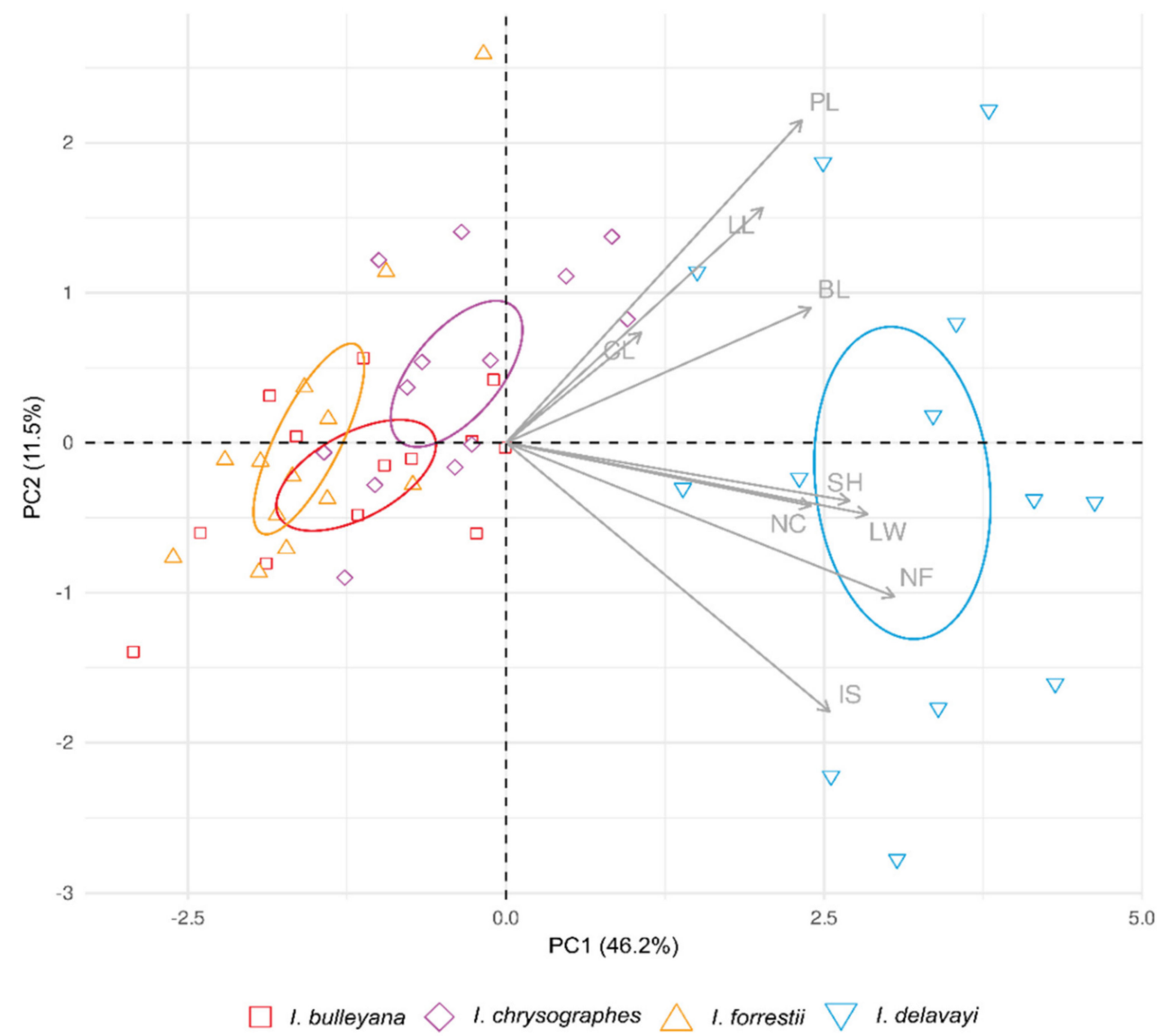

Figure 5. Principal component analysis (PCA) of morphological characters. PCA scatter-plot of the first two principal components based on 9 characters for 52 studied specimens. For character codes, refer to Table 2. The ellipses outline the confidence regions for the species with the respective color.

\section{Discussion}

Based on the sequencing of cpDNA regions for the samples from different localities within the I. ser. Sibiricae distribution range, our study confirms the monophyly of two main divergent lineages and a sister relationship between them. Such a pattern is generally consistent with results of several phylogenetic studies $[6,24,62]$ and supports the splitting of I. ser. Sibiricae into two subseries, as it was previously suggested on the basis of chromosome numbers, morphology, and distribution (e.g., References $[5,11])$. The first lineage contains haplotypes of all samples from the northern part of the range, where one species (I. sibirica) is distributed [1], and the second one contains haplotypes of samples from the southern part of the range, where species of I. ser. Sibiricae with $2 \mathrm{n}=40$ chromosomes are distributed $[11,13,14]$. The high levels of genetic differentiation and nucleotide divergence of cpDNA between these lineages indicate a deep genetic split between them, which may suggest a long independent evolutionary history of species from the two subseries. 
Recently, six taxa at the species rank have been assigned to I. subser. Chrysographes [19]. Based on the cpDNA region sequence analyses, we revealed four distinct genetic lineages (Figures 3 and 4). The values of nucleotide sequence divergence between these lineages (Table S3) are comparable with the divergence between other species in Iris [32,34] and between closely related species in other genera (e.g., References $[63,64]$ ). The lowest value was found between haplogroups A and B (Table S3) forming a single cluster (I) in the phylogenetic analyses (Figure 4), which is indicative of close genetic relationships between the species constituting them. In our study, we could not distinguish genetically between these three taxa with minimally divergent haplotypes lacking species-specific markers and forming a star-like structure in the network, which indicates no deep phylogenetic split between them and is consistent with the rapid range expansion. The species forming haplogroup A, i.e., the bulleyana group, can easily interbreed with each other during cultivation and in the wild and, thus, lose their identity [4,14].

Grey-Wilson [4,11] believed that I. clarkei might perhaps best be placed in a separate group of its own. On the contrary, our molecular data showed that both I. clarkei and I. wilsonii are placed in the monophyletic clade of $I$. subser. Chrysographes as distinct lineages. Dykes [13] suggested that I. forrestii may roughly be described as a dwarf I. wilsonii. It should be noted that, despite the fact that the overall distributions of I. forrestii and I. wilsonii appear to overlap, there is no indication that the two species grow together in the wild and, therefore, their natural hybridization is likely to be ruled out [11]. Moreover, I. forrestii blooms about two weeks earlier than I. wilsonii [65]. Our results suggest a phylogenetic affinity of I. wilsonii with I. clarkei. In addition, the molecular data shows that I. delavayi is the closest species to the species of the bulleyana group and appears as a sister taxon in the same cluster with them. This species is distinct in morphology (Table 3), being, however, more genetically similar to I. chrysographes than to any other of the I. subser. Chrysographes species. Thus, our analyses support the recognition of I. clarkei, I. delavayi, and I. wilsonii as distinct species.

Traditionally, I. clarkei is regarded as unique and holding an isolated position within I. ser. Sibiricae, as it has a solid flowering stem (e.g., References $[10,11,13,14])$. However, according to some authors [20,66] and the herbarium specimens (e.g., L3912484; see Annex 1 ), the flowering stem in I. clarkei is considered to be solid with a small central hollow. We assume that, generally or in some cases, the flowering stem in I. clarkei is not completely solid, with the central part of the stem filled with a broad expanse of pith. Similarly, it is generally accepted that I. wilsonii has an unbranched flowering stem with a terminal inflorescence of two flowers, as we observed when examining the herbarium specimens. Contrary to this, we found specimens of $I$. wilsonii heaving 1-branched flowering stems. These plants were collected in Zhaojue County, Sichuan Province (the gatherings "W. Sun 15" and "Sichuan Vegetation Team 12818"; see Annex 1).

There is a high degree of morphological similarity between specimens belonging to the bulleyana group, which probably results from their close relationship, as indicated by many researchers. As pointed out by Stapf [67] and Dykes [13,22,68], the author of the bulleyana group taxa, I. chrysographes is closely allied to I. forrestii, while differing in color of flowers and in habitats, and I. bulleyana also strongly resembles I. forrestii. According to Noltie $[10,21]$, the evidence of the variability observed in the northwestern Yunnan Province in 1993 provides much support to the idea of treating I. chrysographes and I. bulleyana as forms of the same species differing mainly in the flower color, and our results suggest that this assumption is reasonable. In fact, it was confirmed on the basis of the morphological results that I. bulleyana, I. chrysographes, and I. forrestii have considerable morphological variation, and, even though the studied specimens exhibit continuity of morphological characters, they, however, differ in flower color (Table 3). In addition, the morphometric analysis showed one overlapping group in which the specimens of the bulleyana group were indistinctly separated from each other and formed a single aggregation (Figure 5).

In addition, our examination of the herbarium specimens showed (see Annex 1) that the species of the bulleyana group have the same distribution in China. In the Yunnan 
Province, these are common in Dali Bai Autonomous Prefecture, Diqing Tibetan Autonomous Prefecture (Haba Snow Mountain, Shangri-La county-level city), the Lijiang prefecture-level city (Yulong Naxi Autonomous County, including I. bulleyana f. alba), and Nujiang Lisu Autonomous Prefecture. In the Sichuan Province, these are common in Garzê Tibetan Autonomous Prefecture (Jiulong County), and Liangshan Yi Autonomous Prefecture (Muli and Yanyuan counties); additionally, I. bulleyana and I. chrysographes occur in Ngawa Tibetan and Qiang Autonomous Prefecture (Mianning County). Moreover, as was reported in previous works $[11,14]$ and is confirmed in the present study, I. bulleyana is sometimes found in associations with I. chrysographes and I. forrestii (e.g., the gathering " $C . W$. Wang 63721"; see Annex 1) or in mixed populations of I. bulleyana and I. chrysographes (e.g., the gatherings "G. Forrest 26948”, “C.W. Wang 67662”, “T.T. Yü 11650”, “G. Forrest 25043”, "Tibet Chinese Herbal Medicine Survey Team 3137 \& 4024", "Qinghai-Tibet team 751074", and “Z. Liu 4726").

Thus, I. bulleyana, I. chrysographes, and I. forrestii do not differ in characters that are significant for taxonomic species differentiation within the genus, and the molecular data and morphometric characters selected here are sufficient to confirm this assumption. In such a situation, combining the critical taxa into a single species seems to be appropriate, and many researchers have adopted this approach (e.g., Reference [69]). For this reason, further determination of the three species with their overlapping distribution ranges is obviously not justified, and, therefore, we suggest reconsidering their taxonomic status.

\section{Taxonomic Treatment}

In the present study, we confirm that I. ser. Sibiricae is divided into two groups, the autonymic subseries with a single species I. sibirica [1] and I. subser. Chrysographes. As a consequence of the present work, we consider form rank to be the most suitable option for I. bulleyana, I. chrysographes, and I. forrestii. The earlier described names, I. bulleyana and I. forrestii, were simultaneously published by Dykes [70], both with equal priorities until now. Here, we combine these taxa and establish priority of I. bulleyana over I. forrestii, the other competing name (see Art. 11.5, Note 3 of the ICN).

\subsection{The List of Taxa}

A list of the taxa within I. subser. Chrysographes accepted in the present work and information on species distributions, habitats, and types is provided below.

(1) Iris clarkei Baker ex Hook.f., Fl. Brit. India 6(18): 275, 1892 ELimniris clarkei (Baker ex Hook.f.) Rodion., Bot. Zhurn. 92(4): 551, 2007.-Lectotype (designated by Boltenkov [19] (p. 290)): [India] Sikkim Himal., [fl.], 1848, [Hooker] s.n. (K000098495!, specimens at the flowering stage).—http:/ / specimens.kew.org/herbarium/K000098495 (accessed on 15 September 2021).

Distribution and habitat-This species has a more westerly distribution and is native to the Central and Eastern Himalayas, particularly to northeastern India (the states of Manipur, Sikkim, and West Bengal and the Ladakh union territory), central and eastern Nepal, the Haa and Paro valleys in western Bhutan [71], and northern Myanmar [72]. In southwestern China, it is distributed in the southeastern Xizang Province (the Nyingchi and Shigatse prefecture-level cities) and northwestern Yunnan Province (Nujiang Lisu Autonomous Prefecture). It grows commonly in shady places in marshes, wet meadows, woodland margins, and beside streams and lakes at elevations of $2300-4300 \mathrm{~m}$.

(2) Iris delavayi Micheli, Rev. Hort. 67: 398, 1895 三 Limniris delavayi (Micheli) Rodion., Bot. Zhurn. 92(4): 551, 2007.-Lectotype (designated by Boltenkov [19] (p. 290)): [illustration] "Iris delavayi" in Micheli [73] (p. 399, f. 128).-https:/ / www.biodiversitylibrary.org/ item/197620\#page/437/mode/1up (accessed on 15 September 2021).

Distribution and habitat-This species is distributed in the Chumbi Valley (Yadong County, southeastern Xizang Province, China) and near the Cang Mountains in the northwestern Yunnan Province, China (Dali City and Yangbi Yi Autonomous County). In southwestern China, I. delavayi also occurs in the Guizhou and Sichuan provinces [10]; 
however, we could not confirm its distribution there with any reliable herbarium specimens and, therefore, it requires verification. The populations of this semi-aquatic species are severely fragmented in distribution. They generally grow in damp places along ditches and streams, in wet or marshy mountain meadows, and swampy places at elevations of 2300-3400 m.

(3) Iris wilsonii C.H.Wright, Bull. Misc. Inform. Kew 26(8): 321, $1907 \equiv$ Limniris wilsonii (C.H.Wright) Rodion., Bot. Zhurn. 92(4): 551, 2007.-Lectotype (designated by Boltenkov [19] (p. 292)): [Specimen from a cultivated plant], China, Wilson, Kew, 26 June [19] 07, [fl.], s. coll. 1164a (K000499094!).—http:/ / specimens.kew.org/herbarium/ K000499094 (accessed on 15 September 2021).

Distribution and habitat-It is an endemic to central and southwestern China and has a more easterly distribution: the southeastern Gansu Province (Hui County), the southern Shaanxi Province (Yang, Fuping and Ningshan counties, and the Baoji prefecture-level city), the northern and southern Sichuan Province (Leibo, Mianning, Meigu, Yuexi, and Zhaojue counties, and Ebian Yi Autonomous County), the northern and southern Chongqing municipality (Chengkou, Wushan, and Wuxi counties, and Nanchuan District), and the western Hubei Province (Badong and Fang counties, and Shennongjia Forestry District). It is often found on hillsides, wet meadows, forest edges, along riversides and streams at elevations of 1600-3600 $\mathrm{m}$ and, apparently rarely, above.

(4) Iris bulleyana Dykes, Gard. Chron., ser. 3, 47: 418, 1910 三 Limniris bulleyana (Dykes) Rodion., Bot. Zhurn. 92(4): 551, 2007._-Lectotype (designated by Boltenkov [19] (p. 292)): [China], Fl. blue, Marais, sur le Yu Kia Ngan, au dessus de Pon Man tsen, á 2800 m, [fl.], 3 July 1888, J.M. Delavay 4808 (P02159142 [digital image!]).—http:/ / coldb.mnhn.fr / catalognumber/mnh/p/p02159142 (accessed on 15 September 2021).

Distribution and habitat-This species is endemic to the Hengduan Mountains in southwestern China, where it is very common. It grows in moist areas among grasses on hillsides or forest edges, in meadows, pastures, and beside streams at elevations of 1800-4800 m.

\section{(4.1) Iris bulleyana $f$. bulleyana}

Distribution-In China, it occurs in the northwestern Yunnan Province: Nujiang Lisu Autonomous Prefecture (Gongshan Dulong and Nu Autonomous County), northern Dali Bai Autonomous Prefecture (Jianchuan County), Diqing Tibetan Autonomous Prefecture (Deqin and Weixi Lisu Autonomous counties, and the Shangri-La county-level city), the Lijiang prefecture-level city (Yulong Naxi Autonomous County); in the southwestern Sichuan Province: Garzê Tibetan Autonomous Prefecture (Jiulong and Xiangcheng counties, and the Kangding county-level city), Liangshan Yi Autonomous Prefecture (Muli and Yanyuan counties), Ngawa Tibetan and Qiang Autonomous Prefecture (Zoigê and Mianning counties); and in southeastern Xizang Province: the Nyingchi prefecture-level city (Mainling and Zayü counties, Bayi District). In addition, it occurs in northern Myanmar (Kachin State). (4.2) Iris bulleyana f. forrestii (Dykes) Bolt., comb. et stat. nov. $\equiv$ I. forrestii Dykes, Gard. Chron., ser. 3, 47: 418, 1910 (basionym) $\equiv$ Limniris forrestii (Dykes) Rodion., Bot. Zhurn. 92(4): 551, 2007.—Lectotype (designated by Boltenkov [19] (p. 292)): [China] NW Yunnan, open mountain meadows on the eastern flank of the Lichiang Range, lat. $27^{\circ} 30^{\prime}$ N, alt. 11-12,000 ft., [fl.], June 1906, Forrest 2426 (E00381810!). https: / / data.rbge.org.uk/herb/E00381810 (accessed on 15 September 2021).

Distribution-Northwestern Yunnan Province: the Baoshan and Lijiang (Yulong Naxi Autonomous County) prefecture-level cities, northern Dali Bai Autonomous Prefecture (Heqing County), Diqing Tibetan Autonomous Prefecture (Deqin County and the ShangriLa county-level city), Nujiang Lisu Autonomous Prefecture (Lanping Bai and Pumi Autonomous County, Gongshan Derung and Nu Autonomous County); the southwestern Sichuan Province: Garzê Tibetan Autonomous Prefecture (Jiulong County), Liangshan Yi Autonomous Prefecture (Muli and Yanyuan counties), and the Panzhihua prefecture-level city (Yanbian and Miyi counties). 
(4.3) Iris bulleyana f. chrysographes (Dykes) Bolt., comb. et stat. nov. $\equiv$ I. chrysographes Dykes, Gard. Chron., ser. 3, 49: 362, 1911 (basionym) $\equiv$ Limniris chrysographes (Dykes) Rodion., Bot. Zhurn. 92(4): 551, 2007.-_Lectotype (designated by Boltenkov [19] (p. 293)): [Sichuan Province, China] fl. violet, thickets, common, west of Kuan Hsien [Dujiangyan City], 7-11,000 ft., [fl.], June [19] 08, E.H. Wilson 1304 (K000499091!)—http: / / specimens.kew.org/herbarium/K000499091 (accessed on 15 September 2021).

Distribution-Northwestern Yunnan Province: Nujiang Lisu Autonomous Prefecture (the Lushui county-level city, Lanping Bai and Pumi Autonomous County), Diqing Tibetan Autonomous Prefecture (Weixi Lisu Autonomous County and the Shangri-La county-level city), northern Dali Bai Autonomous Prefecture (Eryuan County), the Lijiang prefecture-level city (Yulong Naxi Autonomous County); Sichuan Province: Garzê Tibetan Autonomous Prefecture (Daocheng and Jiulong counties, and the Kangding county-level city), Ngawa Tibetan and Qiang Autonomous Prefecture (Mao, Mianning, and Wenchuan counties), Liangshan Yi Autonomous Prefecture (Meigu, Muli, and Yanyuan counties); the southeastern Xizang Province: the Nyingchi prefecture-level city (Mainling County and Bayi District).

(4.4) Iris bulleyana f. alba Y.T.Zhao, Acta Phytotax. Sin. 18(1): 54, 1980.-Holotype: [Yunnan Province, China], Atuntze, mt. Paima Shan [Baimang Xueshan (Snow Mountains)], hillside, 3510 m, [fl.], 6 July 1937, T.T. Yü 8749 (KUN0360168 [digital image!]).—https: / / www.cvh.ac.cn/spms / detail.php?id=ffb63158 (accessed on 15 September 2021).

Distribution-This is the rarest representative of I. bulleyana, found in the Yunnan Province: the Lijiang prefecture-level city (Yulong Naxi Autonomous County) and Diqing Tibetan Autonomous Prefecture (Deqin County).

\subsection{The Key}

Below is a key to the I. subser. Chrysographes taxa recognized in the present study.

1. Flowering stem nearly solid, usually 1-2-branched in the upper part; standards strongly inclined ... Iris clarkei

1. Flowering stem hollow, 1-branched or unbranched; standards nearly erect or obliquely spreading ... 2

2. Flowering stem usually more than $100 \mathrm{~cm}$ tall and higher than rosette leaves, 1branched; rosette leaves usually more than $1 \mathrm{~cm}$ wide, without obvious midribs; standards obliquely spreading ... Iris delavayi

2. Flowering stem up to $73 \mathrm{~cm}$ tall, almost as long as rosette leaves, with terminal inflorescence of 1-2 flowers; rosette leaves with obvious midribs, usually less than $1.1 \mathrm{~cm}$ in width; standards nearly erect ... 3

3. Pedicels usually elongated (up to $11 \mathrm{~cm}$ long); flowers pale yellow ... Iris wilsonii

3. Rosette leaves without obvious midribs; pedicels not exceeding $9 \mathrm{~cm}$ in length; standards inclined at an angle of $45^{\circ}$; flowers vary in color . . 4

4a. Flower color variable, from pale blue to mauve and violet; blades of falls with white or yellow mottled and striped pattern ... Iris bulleyana f. bulleyana

4b. Flowers usually lemon-yellow ... Iris bulleyana f. forrestii

4c. Flower color variable, from reddish violet to deep violet; blades of falls often with golden yellow stripes... Iris bulleyana f. chrysographes

$4 \mathrm{~d}$. Flowers white... Iris bulleyana f. alba

\section{Conclusions}

Here, we, for the first time, resolve the phylogenetic relationships of the $I$. ser. Sibiricae species and confirm the monophyly of two divergent lineages, subseries, and their taxonomic statuses. Our preliminary analyses highlight the need for a comprehensive study of genetic and morphological divergence in order to clarify the taxonomy of I. subser. Chrysographes, better known to horticulturists as Sino-Siberians. We have obtained molecular evidence and revised the plant morphology and distribution. Our perhaps most important conclusion is that a revision of some of the species-level taxa is required. Once again, we 
have shown that the chloroplast markers $\operatorname{trnS}-\operatorname{trn} G, \operatorname{trnL} L-t r n F, r p s 4-t r n S^{\mathrm{GGA}}$, and $p s b A-$ $\operatorname{trn} H$ provide a reliable resolution of the species and are optimal molecular markers for identifying taxonomic and phylogenetic relationships within critical taxa of the genus Iris.

The four lineages of I. subser. Chrysographes correspond to four morphologically distinct, biogeographically congruent groups: I. clarkei in the western part of the range, $I$. wilsonii in the eastern part, and I. delavayi and a complex of I. bulleyana, I. chrysographes, and I. forrestii in the central part of the range. In addition, our data show that the morphological characters of I. bulleyana, I. chrysographes, and I. forrestii were within the range of variation of a single species to which they are assigned. A morphometric analysis based on nine morphological characters has not revealed any separation between the three taxa. In congruence with the molecular data, I. bulleyana, I. chrysographes, and I. forrestii show weak morphological differentiation and, thus, are better to be treated as color forms of the same species. Based on our present results, we accept I. clarkei, I. delavayi, and I. wilsonii in their traditional concepts and recognize the other three taxa as a single species. Therefore, we suggest two combinations, I. bulleyana f. forrestii and I. bulleyana f. chrysographes.

Molecular evidence obtained in this study contribute to the knowledge of the taxonomy of irises and their distribution in China. Thus, one of the goals set for the future is to produce a thoroughly verified, sufficiently sampled, and robust phylogenetic tree that would provide a basis for a revised phylogeny of Iris s.l. Furthermore, a thorough re-examination of some morphological characters is also needed, using a broader set of samples across the entire distribution ranges of the species considered, since we still lack adequate understanding of the flowering stem structure in I. clarkei and the flowering stem branching in I. wilsonii.

Supplementary Materials: The following are available online at https:/ /www.mdpi.com/article/10 .3390 /plants10112232/s1, Annex 1: Complete list of specimens examined in the morphological analysis, Table S1: Raw data of the morphological analysis, Table S2: The results of the variance analysis of the Iris subser. Chrysographes species, Table S3: Nucleotide divergence between groups identified by the MJ (four haplogroups) and phylogenetic analyses (three clusters) of Iris subser. Chrysographes from 25 localities, and also between I. bulleyana, I. forrestii, and I. chrysographes (haplogroup A) and I. delavayi (haplogroup B) as inferred from the cpDNA data.

Author Contributions: Conceptualization, E.V.B.; methodology, E.V.B. and E.V.A.; software, E.V.B. and E.V.A.; validation, E.V.B., E.V.A., and A.T.-B.; formal analysis, E.V.B. and E.V.A.; investigation, E.V.B. and E.V.A.; resources, E.V.B. and A.T.-B.; data curation, E.V.B.; writing —original draft preparation, E.V.B. and E.V.A.; writing — review and editing, E.V.B., E.V.A. and A.T.-B.; visualization, E.V.B. and E.V.A.; supervision, E.V.B. and A.T.-B.; project administration, E.V.B. All authors have read and agreed to the published version of the manuscript.

Funding: This research received no external funding.

Data Availability Statement: Sequences resulting from this study are deposited in GenBank.

Acknowledgments: We are grateful to the curators and the staff of the consulted herbaria for making specimens available for our study. We acknowledge the support from the RBGE (UK) as a supplier of plant material, from John Mitchell and Peter Brownless who rendered us assistance and gave helpful information, and from Henry Noltie who also provided useful information. Special thanks are due to Christof Schröder (a historical herbariologist and field botanist, Heidelberg) and his wife Christina for their kind assistance in deciphering some of the herbarium labels from P. We also thank Oleg Kolesnik (Uzhhorod National University, Ukraine), Tatiana Gaidash (Krasnodar, Russia), Ori Fragman-Sapir (The Jerusalem Botanical Gardens), Rob Cubey (RBGE), Richard Wilford (Royal Botanic Gardens, Kew), Natalia Shevyreva (Main Botanical Garden, Moscow), and Irina Illarionova (Komarov Botanical Institute, St. Petersburg), who generously provided and permitted to use photographs of irises.

Conflicts of Interest: The authors declare no conflict of interest. 


\begin{abstract}
Abbreviations
The following abbreviations are used in this manuscript. ANOVA, Analysis of variance; BI, Bayesian inference analyses; BP, Bootstrap percentage; cpDNA, Chloroplast DNA; CV, Coefficient of variation; DNA, Deoxyribonucleic acid; $F_{\mathrm{ST}}$, Pairwise genetic distances; ICN, International Code of Nomenclature for algae, fungi, and plants; $K_{\mathrm{S}}$, Nucleotide sequence divergence; MCMC Markov chain Monte Carlo methods; MJ, Median joining algorithm; ML, Maximum likelihood method; MP, Maximum parsimony method; PCA, Principal component analysis; PCR, Polymerase chain reaction; PP, Bayesian posterior probabilities; RBGE, Royal Botanic Garden Edinburgh; TBR, Tree bisection-reconnection.
\end{abstract}

\title{
References
}

1. Boltenkov, E.; Artyukova, E.; Kozyrenko, M.; Erst, A.; Trias-Blasi, A. Iris sanguinea is conspecific with I. sibirica (Iridaceae) according to morphology and plastid DNA sequence data. PeerJ 2020, 8, e10088. [CrossRef]

2. $\quad$ Diels, L. Iridaceae. In Die Natürlichen Pflanzenfamilien, 2nd ed.; Engler, A., Prantl, K., Eds.; W. Engelmann: Leipzig, Germany, 1930; Volume 15a, pp. 463-505.

3. Simonet, M. Nouvelles recherché cytologiques et génétiques chez les Iris. Ann. Sci. Nat. Bot. Ser. 10 1934, 16, $229-383$.

4. Grey-Wilson, C. The Genus Iris, Subsection Sibiricae; British Iris Society: London, UK, 1971.

5. Lenz, L.W. A reclassification of the Siberian irises. Aliso 1976, 8, 379-381. [CrossRef]

6. Tillie, N.; Chase, M.W.; Hall, T. Molecular studies in the genus Iris L.: A preliminary study. Ann. Bot. N. Ser. 2000, 58, 105-112.

7. Wheeler, A.S.; Wilson, C.A. Exploring phylogenetic relationships within a broadly distributed Northern Hemisphere group of semi-aquatic Iris species (Iridaceae). Syst. Bot. 2014, 39, 759-766. [CrossRef]

8. Lu, J.-M.; Xie, H.; Zhang, H.-Q.; Wu, M.-J.; Xia, H.-M. On the karyotype studies of wild horticulture species of Iris. Bull. Bot. Res. Harbin 1994, 14, 37-39.

9. Probatova, N.S. Chromosome numbers of plants of the Primorsky Territory, the Amur River basin and Magadan region. Bot. Zhurn. 2006, 91, 491-509.

10. Zhao, Y.-T.; Noltie, H.J.; Mathew, B. Iridaceae. In Flora of China; Wu, Z.-Y., Raven, P.H., Eds.; Science Press: Beijing, China; Missouri Botanical Garden Press: St. Louis, MO, USA, 2000; Volume 24, pp. 297-313.

11. Grey-Wilson, C. Series Sibiricae (Diels) Lawrence. In A Guide to Species Irises: Their Identification and Cultivation; The Species Group of the British Iris Society, Ed.; Cambridge University Press: Cambridge, UK, 2012; pp. 133-144.

12. Claire, A. Irises: A Garden Encyclopedia; Timber Press: Portland, OR, USA, 2005.

13. Dykes, W.R. The Genus Iris; Cambridge University Press: Cambridge, UK, 1913. [CrossRef]

14. Mathew, B. The Iris, 2nd ed.; Timber Press: Portland, OR, USA, 1989.

15. Rodionenko, G.I. On the independence of the genus Limniris (Iridaceae). Bot. Zhurn. 2007, 92, 547-554.

16. Crespo, M.B.; Martínez-Azorín, M.; Mavrodiev, E.V. Can a rainbow consist of a single colour? A new comprehensive generic arrangement of the 'Iris sensu latissimo' clade (Iridaceae), congruent with morphology and molecular data. Phytotaxa 2015, 232, 1-78. [CrossRef]

17. Lynch, R.I. The Book of the Iris; J. Lane: London, UK; New York, NY, USA, 1904. [CrossRef]

18. Waddick, J.W.; Zhao, Y.-T. Iris of China; Timber Press: Portland, OR, USA, 1992.

19. Boltenkov, E.V. Typification of nine names referable to Iris subser. Chrysographes (Iridaceae) with some taxonomic notes. Phytotaxa 2019, 408, 289-295. [CrossRef]

20. Noltie, H.J. Flora of Bhutan: Including a Record of Plants from Sikkim and Darjeeling; Royal Botanic Garden: Edinburgh, UK, 1994; Volume 3.

21. Noltie, H. New irises from Yunnan. N. Plantsman 1995, 2, 131-140.

22. Dykes, W.R. A Handbook of Garden Irises; M. Hopkinson \& Co.: London, UK, 1924.

23. CBOL Plant Working Group. A DNA barcode for land plants. Proc. Natl. Acad. Sci. USA 2009, 106, 12794-12797. [CrossRef]

24. Wilson, C.A. Phylogenetic relationships among the recognized series in Iris section Limniris. Syst. Bot. 2009, 34, 277-284. [CrossRef]

25. Dong, W.; Liu, J.; Yu, J.; Wang, L.; Zhou, S. Highly variable chloroplast markers for evaluating plant phylogeny at low taxonomic levels and for DNA barcoding. PLoS ONE 2012, 7, e35071. [CrossRef]

26. Kress, W.J. Plant DNA barcodes: Applications today and in the future. J. Syst. Evol. 2017, 55, 291-307. [CrossRef]

27. Wilson, C.A.; Padiernos, J.; Sapir, Y. The royal irises (Iris subg. Iris sect. Oncocyclus): Plastid and low-copy nuclear data contribute to an understanding of their phylogenetic relationship. Taxon 2016, 65, 35-46. [CrossRef]

28. Shneyer, V.S.; Rodionov, A.V. Plant DNA Barcodes. Biol. Bull. Rev. 2019, 9, 295-300. [CrossRef]

29. Kang, Y.J.; Kim, S.; Lee, J.; Won, H.; Nam, G.-H.; Kwak, M. Identification of plastid genomic regions inferring species identity from de novo plastid genome assembly of 14 Korean-native Iris species (Iridaceae). PLoS ONE 2020, 15, e0241178. [CrossRef] [PubMed] 
30. Shaw, J.; Lickey, E.B.; Beck, J.T.; Farmer, S.B.; Liu, W.; Miller, J.; Siripun, K.C.; Winder, C.T.; Schilling, E.E.; Small, R.L. The tortoise and the hare II: Relative utility of 21 noncoding chloroplast DNA sequences for phylogenetic analysis. Am. J. Bot. 2005, 92, 142-166. [CrossRef] [PubMed]

31. Kim, S.-C.; Crawford, D.J.; Jansen, R.K.; Santos-Guerra, A. The use of a non-coding region of chloroplast DNA in phylogenetic studies of the subtribe Sonchinae (Asteraceae: Lactuceae). Plant Syst. Evol. 1999, 215, 85-99. [CrossRef]

32. Kozyrenko, M.M.; Artyukova, E.V.; Zhuravlev, Y.N. Independent species status of Iris vorobievii N.S.Pavlova, Iris mandshurica Maxim., and Iris humilis Georgi (Iridaceae): Evidence from the nuclear and chloroplast genomes. Russ. J. Genet. 2009, 45, 1394-1402. [CrossRef]

33. Boltenkov, E.V.; Artyukova, E.V.; Kozyrenko, M.M. Species divergence in Iris series Lacteae (Iridaceae) in Russia and adjacent countries based on chloroplast DNA sequence data. Russ. J. Genet. 2016, 52, 507-516. [CrossRef]

34. Boltenkov, E.V.; Artyukova, E.V.; Kozyrenko, M.M.; Trias-Blasi, A. Iris tibetica, a new combination in I. ser. Lacteae (Iridaceae) from China: Evidence from morphological and chloroplast DNA analyses. Phytotaxa 2018, 338, 223-240. [CrossRef]

35. Boltenkov, E.V. Typification of the name Iris sanguinea (Iridaceae). Phytotaxa 2018, 345, 175-178. [CrossRef]

36. Thiers, B. Index Herbariorum: A Global Directory of Public Herbaria and Associated Staff. New York Botanical Garden's Virtual Herbarium, USA. Available online: https:/ / sweetgum.nybg.org/ih/ (accessed on 15 September 2021).

37. Kozyrenko, M.M.; Artyukova, E.V.; Boltenkov, E.V.; Lauve, L.S. Somaclonal variability of Iris pseudacorus L. according to RAPD and cytogenetic analyses. Biotechnol. Russ. 2004, 2, 11-22.

38. Bonfield, J.K.; Smith, K.F.; Staden, R. A new DNA sequence assembly program. Nucleic Acids Res. 1995, 23, 4992-4999. [CrossRef] [PubMed]

39. Gouy, M.; Guindon, S.; Gascuel, O. SeaView version 4: A multiplatform graphical user interface for sequence alignment and phylogenetic tree building. Mol. Biol. Evol. 2010, 27, 221-224. [CrossRef]

40. Librado, P.; Rozas, J. DnaSP v5: A software for comprehensive analysis of DNA polymorphism data. Bioinformatics 2009, 25, 1451-1452. [CrossRef]

41. Bandelt, H.-J.; Forster, P.; Röhl, A. Median-joining networks for inferring intraspecific phylogenies. Mol. Biol. Evol. 1999, 16, 37-48. [CrossRef]

42. Swofford, D.L. PAUP*: Phylogenetic Analysis Using Parsimony ( ${ }^{*}$ and Other Methods), Version 4.0 b10; Sinauer Associates: Sunderland, MA, USA, 2002. [CrossRef]

43. Ronquist, F.; Huelsenbeck, J.P. MrBayes 3: Bayesian phylogenetic inference under mixed models. Bioinformatics 2003, 19, 1572-1574. [CrossRef]

44. Miller, M.A.; Pfeiffer, W.; Schwartz, T. Creating the CIPRES Science Gateway for inference of large phylogenetic trees. In Proceedings of the Gateway Computing Environments Workshop (GCE 2010), New Orleans, LA, USA, 14 November 2010; Volume 1, pp. 1-8. [CrossRef]

45. Simmons, M.P.; Ochoterena, H. Gaps as characters in sequence-based phylogenetic analyse. Syst. Biol. 2000, 49, 369-381. [CrossRef] [PubMed]

46. Borchsenius, F. FastGap 1.2; University of Aarhus: Aarhus, Denmark, 2009; Available online: https://www.aubot.dk/FastGap_ home.htm (accessed on 15 September 2021).

47. Posada, D.; Crandall, K.A. Modeltest: Testing the model of DNA substitution. Bioinformatics 1998, 14, 817-818. [CrossRef] [PubMed]

48. Excoffier, L.; Lischer, H.E.L. Arlequin suite ver 3.5: A new series of programs to perform population genetics analyses under Linux and Windows. Mol. Ecol. Resour. 2010, 10, 564-567. [CrossRef] [PubMed]

49. Ihaka, R.; Gentleman, R. R: A language for data analysis and graphics. J. Comput. Graph. Stat. 1996, 5, 299-314. [CrossRef]

50. R Core Team. R: A Language and Environment for Statistical Computing; R Foundation for Statistical Computing: Vienna, Austria, 2021; Available online: https: / / www.r-project.org/ (accessed on 15 September 2021).

51. Benjamini, Y.; Hochberg, Y. Controlling the false discovery rate: A practical and powerful approach to multiple testing. J. R. Stat. Soc. Ser. B Stat. Methodol. 1995, 57, 289-300. [CrossRef]

52. Fox, J.; Weisberg, S. An \{R\} Companion to Applied Regression, 3rd ed.; Sage: Thousand Oaks, CA, USA, 2019.

53. Hothorn, T.; Bretz, F.; Westfall, P. Simultaneous inference in general parametric models. Biom. J. 2008, 50, 346-363. [CrossRef]

54. Zeileis, A. Econometric computing with HC and HAC covariance matrix estimators. J. Stat. Soft. 2004, 11, 1-17. [CrossRef]

55. Zeileis, A. Object-oriented computation of sandwich estimators. J. Stat. Soft. 2006, 16, 1-16. [CrossRef]

56. Sneath, P.H.A.; Sokal, R.R. Numerical Taxonomy: The Principles and Practices of Numerical Classification; Freeman: San Francisco, CA, USA, 1973.

57. Valcárcel, V.; Vargas, P. Quantitative morphology and species delimitation under the general lineage concept: Optimization for Hedera (Araliaceae). Am. J. Bot. 2010, 97, 1555-1573. [CrossRef]

58. Kassambara, A.; Mundt, F. factoextra: Extract and Visualize the Results of Multivariate Data Analyses, version 1.0.7. Available online: https: / /CRAN.R-project.org/package=factoextra (accessed on 15 September 2021).

59. Turland, N.J.; Wiersema, J.H.; Barrie, F.R. (Eds.) International Code of Nomenclature for Algae, Fungi, and Plants (Shenzhen Code) Adopted by the Nineteenth International Botanical Congress Shenzhen, China, July 2017. [Regnum Vegetabile Volume 159]; Koeltz Botanical Books: Glashütten, Germany, 2018. [CrossRef] 
60. Brummitt, R.K. Species, subspecies, variety or form-An old problem revisited in tropical African Protea. Mitt. Inst. Allg. Bot. Hambg. 1990, 23b, 677-682.

61. Fu, L.; Hong, T. Higher Plants of China; Qingdao Publishing House: Qingdao, China, 2002; Volume 13.

62. Mavrodiev, E.V.; Martínez-Azorín, M.; Dranishnikov, P.; Crespo, M.B. At least 23 genera instead of one: The case of Iris L. s.1. (Iridaceae). PLoS ONE 2014, 9, e106459. [CrossRef]

63. Slotte, T.; Ceplitis, A.; Neuffer, B.; Hurka, H.; Lascoux, M. Intrageneric phylogeny of Capsella (Brassicaceae) and the origin of the tetraploid C. bursa-pastoris based on chloroplast and nuclear DNA sequences. Am. J. Bot. 2006, 93, 1714-1724. [CrossRef]

64. Artyukova, E.V.; Kozyrenko, M.M.; Boltenkov, E.V.; Gorovoy, P.G. One or three species in Megadenia (Brassicaceae): Insight from molecular studies. Genetica 2014, 142, 337-350. [CrossRef]

65. Boland, T. The Siberian and Sino-Siberian Iris Species. Available online: https://davesgarden.com/guides/articles/view/2668 (accessed on 15 September 2021).

66. Service, N. Iris clarkei. In Iris Year Book; The British Iris Society: London, UK, 1979; pp. 59-62.

67. Stapf, O. Iris chrysographes. Curtis's Bot. Mag. Ser. 4 1912, 8, t. 8433.

68. Dykes, W.R. Iris chrysographes. Gard. Chron. Ser. 3 1911, 49, 362-363.

69. Naczk, A.M.; Górniak, M.; Szlachetko, D.L.; Ziętara, M.S. Plastid DNA haplotype diversity and morphological variation in the Dactylorhiza incarnata / maculata complex (Orchidaceae) in northern Poland. Bot. J. Linn. Soc. 2015, 178, 121-137. [CrossRef]

70. Dykes, W.R. Three new Chinese irises. Gard. Chron. Ser. 3 1910, 47, 418.

71. Das, D. Materials for the flora of Bhutan: Iridaceae. Rec. Bot. Surv. India 1973, 20, 222-223.

72. Kress, W.J.; DeFilipps, R.A.; Farr, E.; Kyi, D.Y.Y. A checklist of the trees, shrubs, herbs, and climbers of Myanmar. Contr. U.S. Natl. Herb. 2003, 45, 1-590.

73. Micheli, M. Iris delavayi, espèce nouvelle du Yunnan. Rev. Hort. 1895, 67, 398-399. 